J. Lake Sci. (湖泊科学), $2007, \mathbf{1 9}(4): 373-381$

http://www. jlakes.org. E-mail: jlakes@ niglas. ac.cn

(c) 2007 by Journal of Lake Sciences

\title{
太湖浮游细菌种群基因多样性及其季节变化规律
}

\author{
邢 鹏 ${ }^{1,2}$, 孔繁翔 ${ }^{1 * *}$, 高 光 ${ }^{1}$
}

(1: 中国科学院南京地理与湖泊研究所,南京 210008)

(2: 中国科学院研究生院, 北京 100039 )

摘 要: 为认识湖泊中浮游细菌的多样性及其变化规律, 本研究采用聚合酶链式反应 - 变性梯度凝胶电泳 (PCR-DGGE) 的方法,研究了太湖梅梁湾和湖心区浮游细菌种群 $16 \mathrm{~S} \mathrm{rRNA}$ 基因多样性以及种群基因组成的季节变化特征. 研究结果 表明,太湖浮游细菌种群具有丰富的基因多样性. 浮游细菌的丰度、DGGE 条带数、种群的 Shannon-Wiener 指数、Simpson 指数和 Pielou 指数均呈现显著的季节变化规律: 夏季及秋季浮游细菌的丰度、基因多样性及种群的均匀度较高, 而冬季和 春季则较低. 浮游细菌种群的基因组成随时间变化. 梅梁湾浮游细菌的丰度显著高于湖心. 梅梁湾与湖心浮游细菌主要 建群种的基因型存在显著差异.

关键词: PCR-DGGE; 浮游细菌; 基因多样性;季节变化;太湖

\section{Phylogenetic diversity and seasonal variation of bacterioplankton communities in Lake Taihu}

\author{
XING Peng ${ }^{1,2}$, KONG Fanxiang ${ }^{1 * *}$ \& GAO Guang ${ }^{1}$ \\ (1: Nanjing Institute of Geography and Limnology, Chinese Academy of Sciences, Nanjing 210008, P. R. China) \\ (2: Graduate School of Chinese Academy of Sciences, Beijing 100039, P. R. China)
}

\begin{abstract}
The phylogenetic diversity and seasonal variation of the bacterioplankton communities were determined using denaturing gradient gel electrophoresis (DGGE) of PCR-amplified bacterial 16s rRNA genes at Meiliang Bay and lake center in Taihu. Results indicated that the bacterioplankton community composition was diverse in Lake Taihu. At the two sampling stations, bacterioplankton abundance, DGGE band number, Shannon-Wiener index, Simpson index, and Pielou index all showed significantly seasonal variation during the sampling period. Bacterioplankton abundance, diversity and evenness were all higher in summer and autumn than in winter and spring. The phylogenetic types of the bacterioplankton communities changed during the sampling period. The abundance of bacterioplankton was significantly higher at Meiliang Bay than at the open lake. The main edificators of the bacterioplankton communities may have different phylogenic types at Meiliang Bay and lake center.
\end{abstract}

Keywords:PCR-DGGE; bacterioplankton; phylogenetic diversity; seasonal variation; Lake Taihu

湖泊生态系统中的浮游细菌不仅数量众多,而且种类丰富、功能各异. 浮游细菌对微食物网的能量流 动和物质循环起着关键性作用, 同时, 浮游细菌的活性水平和种群的动态变化又受到复杂的生物和生态关 系的调控 ${ }^{[1]}$. 对浮游细菌种群的深人研究有助于了解微食物网的结构和功能以及微食物网中各营养级的 相互作用. 但是, 仅有极少种类的环境细菌可以在实验室被分离培养, 而且分离培养的方法无法获得细菌 在生态系统中的原位信息 ${ }^{[2]}$. 自 Muyzer G 等首先将聚合酶链式反应 - 变性梯度凝胶电泳 (PCR-Denaturing Gradient Gel Electrophoresis, PCR-DGGE) 应用于微生物生态领域以来,该技术迅速发展, 目前已成为分析环

* 国家重点基础研究发展计划 (2002CB412300)、国家自然科学基金项目 (40471045)、中国科学院百人计划项目和中 科院南京地理与湖泊研究所所长基金联合资助. 2006-08-06 收稿; 2006-09-18 收修改稿. 邢鹏, 女, 1979 年 生,博士研究生; E-mail:pxing@ niglas.ac.cn.

** 通讯作者; E-mail:fxkong@ niglas. ac.cn. 
境微生物群落结构的重要手段之一. 与其他分子指纹技术, 如限制性末端片断长度多态性 ( Terminal Restriction Fragment Length Polymorphism, T-RFLP)，自动核糖体基因间隔区分析(Automated Ribosomal Intergenic Spacer Analysis, ARISA) 等相比,DGGE 的优势在于可以在初步认识基因多样性的基础上,通过对感兴 趣条带的回收、克隆和基因序列测定获得细菌的分类信息. 近年来 PCR-DGGE 也广泛用于湖泊生态系统中 的微生物研究. 通过对浮游细菌 DGGE 电泳图谱的分析, 可以认识浮游细菌种群组成及时空变化 ${ }^{[1,3,4]}$; 研 究环境因子与浮游细菌的相互作用 ${ }^{[5,6]}$; 获得优势种的遗传信息 ${ }^{[7]}$.

Kent 等 $^{[8]}$ 的研究显示湖泊生态系统中,不仅浮游细菌的数量和生物量呈现季节变化的特征,而且浮游 细菌种群的基因多样性成也呈现出随时间变化的趋势. 高光等 ${ }^{[9]}$ 对太湖浮游细菌的研究显示细菌的丰度、 细胞体积、细胞碳含量及细菌生物量具有显著的时空差异,但对太湖浮游细菌种群的基因多样性及季节变 化的研究至今仍未见报到. 本研究采用 PCR-DGGE 方法研究了梅梁湾和大太湖浮游细菌种群的基因多样 性特征, 以进一步认识湖泊中浮游细菌群落结构特征及其随季节和水体营养化程度变化而发生变化的基本 规律.

\section{1 材料与方法}

\section{1 采样点和样品采集}

梅梁湾位于太湖北部,水面面积约 $100 \mathrm{~km}^{2}$, 是目前太湖富营养化程度最为严重的区域之一; 相对于梅 梁湾, 大太湖营养盐水平较低, 但水体受风浪的扰动较大. 本研究选取的两个采样点分别位于梅梁湾的中 心 (湾心, $31^{\circ} 28^{\prime} 36^{\prime \prime} \mathrm{N}, 120^{\circ} 11^{\prime} 49^{\prime \prime} \mathrm{E}$ ) 和大太湖 (湖心, $31^{\circ} 20^{\prime} 22^{\prime \prime} \mathrm{N}, 120^{\circ} 10^{\prime} 51^{\prime \prime} \mathrm{E}$ ) (图 1). 自 2005 年 4 月至 2006 年 3 月 (除 2006 年 1 月份外), 每月中旬采样一次. 水样取自水面下 $50 \mathrm{~cm}$, 每点连续采样 3 次, 快速送 回实验室分析. 从 3 个平行样品中取相同体积的水样,混合均匀, 经超声波处理 ${ }^{[10]}$, 用孔径为 $3 \mu \mathrm{m}$ 的滤膜 预过滤, 除去浮游藻类及其他较大的颗粒. 取 $300-500 \mathrm{ml}$ 滤液负压过滤到孔径为 $0.2 \mu \mathrm{m}$ 的聚碳酸酯膜 上, 将膜保存在 $-20^{\circ} \mathrm{C}$, 用于浮游细菌基因组 DNA 的提取. 另取 $20 \mathrm{ml}$ 滤液加人甲醛固定 $(4 \%, \mathrm{v} / \mathrm{v})$ 用于浮 游细菌计数.

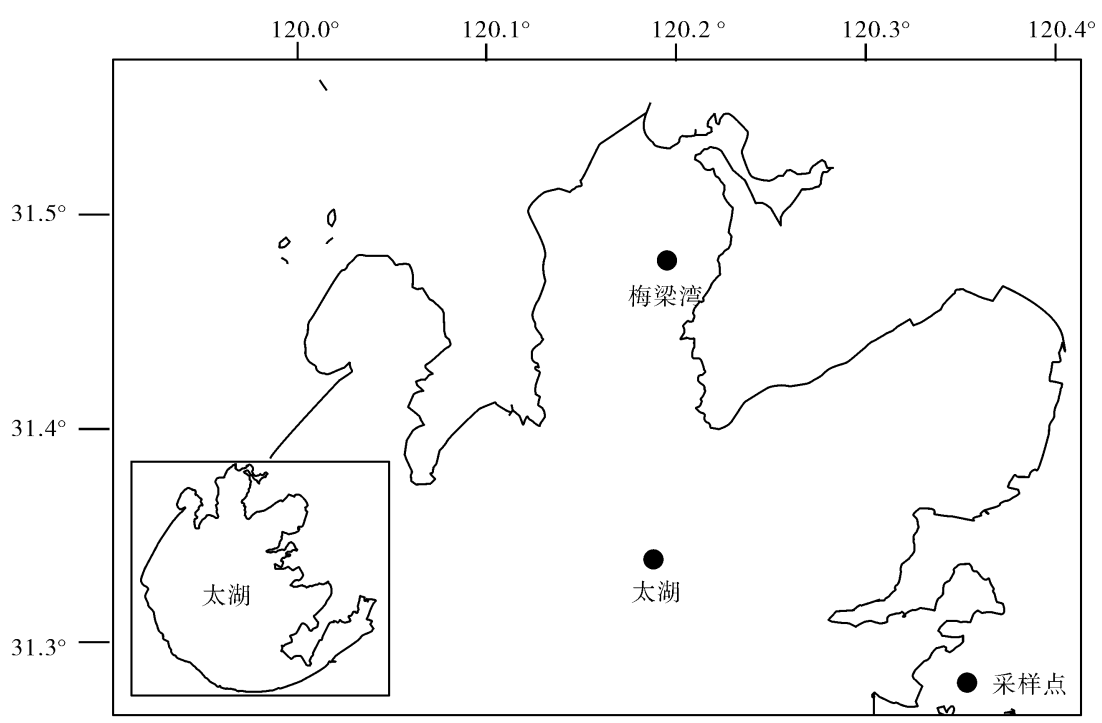

图 1 太湖北部示意图及梅梁湾和湖心采样点位置

Fig. 1 Map of the northern part of Lake Taihu and the sampling sites in Meiliang Bay and the opening lake 


\section{2 浮游细菌的数量及生物量}

浮游细菌的计数采用 DAPI $(0.1 \%, \mathrm{wt} / \mathrm{vol})$ 染色, 苂光显微镜直接计数, 每个样品计数不少于 20 个 视野 $^{[11]}$.

\section{3 浮游细菌种群组成分析}

1.3.1 基因组 DNA 的提取和纯化 浮游细菌样品基因组 DNA 的提取及纯化方法参照参考文献 [12]. 通过 测定产物在 $260 \mathrm{~nm}$ 处的吸光度值及 $260 \mathrm{~nm}$ 与 $280 \mathrm{~nm}$ 吸光度的比值确定提取的基因组 DNA 的浓度和纯 度. 提取的基因组 DNA 置于 $-20^{\circ} \mathrm{C}$ 保存.

1.3.2 PCR-DGGE 分析浮游细菌种群组成采用针对细菌 $16 \mathrm{~S} \mathrm{rDNA}$ 的特异性引物 $341 \mathrm{~F}$ ( 5 ' -CCTACGGGAGGCAGCAG) 和 907R ( 5' -CCGTCAATTCA/CTTTGAGTTT) 对样品基因组 DNA 进行 PCR 扩增 ${ }^{[13]}$, 根据 DGGE 分析的需要, 引物 $341 \mathrm{~F}$ 的 5 '端连有 40 个碱基组成的 GC 夹 (5'-CGCCCGCCGCGCGCGGCGGGCGGGGCGGGGGCACGGGGGG $)^{[14]}$. 采用 Touchdown PCR 增加反应的特异性, 共 30 个循环. 反应条 件如下: $95^{\circ} \mathrm{C}$ 变性 $5 \mathrm{~min}, 94^{\circ} \mathrm{C}$ 变性 $1 \mathrm{~min}, 65-55^{\circ} \mathrm{C}$ ( 每循环下降 $1{ }^{\circ} \mathrm{C}, 10$ 个循环, 至 $56^{\circ} \mathrm{C}$ ) 退火 $30 \mathrm{~s}, 72^{\circ} \mathrm{C}$ 延伸 $1 \mathrm{~min}$,采用 $55^{\circ} \mathrm{C}$ 退火循环 20 次. 最后 $72^{\circ} \mathrm{C}$ 延伸 $30 \mathrm{~min}^{[15]}$. PCR 产物用 $1.5 \%$ 琼脂糖凝胶电泳, EB 染色检 测 PCR 反应扩增效果.

采用美国 CBS 公司电泳仪进行变性梯度凝胶电泳(DGGE)。用梯度混合器制作浓度 $6 \%$ 、厚度 $1 \mathrm{~mm}$ 的 聚丙烯酰胺变性胶,选用变性剂梯度 40\%-70\% (100\% 变性剂含有 $7 \mathrm{~mol} / \mathrm{L}$ 尿素和 $40 \%$ ( v/v) 去离子甲酰 胺). 电泳缓冲液为 $1 \times \mathrm{TAE}(20 \mathrm{mmol} / \mathrm{L}$ Tris, $10 \mathrm{mmol} / \mathrm{L}$ acetate, $0.5 \mathrm{mmol} / \mathrm{L} \mathrm{EDTA}, \mathrm{pH} 8.0)$. 电泳样品的同 时每次需加人自制的 marker 作为对照. $60^{\circ} \mathrm{C}$, 恒压 $100 \mathrm{~V}$ 电泳 $16-18 \mathrm{~h}$. 电泳结束后, DGGE 胶用 SYBR Green I (1: 10000 稀释, Molecular Probe Inc.) 染色 15-30 min, Omega 10 ${ }^{\mathrm{TM}}$ 全自动多功能凝胶成像分析系 统拍照.

\section{4 统计分析}

使用 Gel-Pro 4.5 软件 (Media Cybernetics, USA) 对拍摄的电泳照片进行分析, 比较各条带电泳迁移的 相对位置, 识别条带在泳道中的相对含量. 根据各样品检测到的 DGGE 条带数及各条带的相对含量, 分别 计算浮游细菌种群的 Shannon-Wiener 指数 $\left(H^{\prime}\right)^{[16]}$, Simpson 指数 $(D)^{[17]}$ 和 Pielou 指数 $(J)^{[18]}$, 其中 Shannon-Wiener 指数受物种丰富度影响较大, Simpson 指数较多的反映了物种的优势度, Pielou 指数则是物种均 一性的度量(计算方法见表 1)。

表 1 表征浮游细菌种群特征指数

Tab. 1 Characteristic indices for bacterioplankton communities

\begin{tabular}{cc}
\hline 特征指数 & 计算公式 \\
\hline Shannon-Wiener 指数 & $H^{\prime}=-\sum_{i=1}^{n} P_{i} \ln P_{i}$ \\
Simpson 指数 & $D=\sum_{i=1}^{n} P_{i}^{2}$ \\
Pielou 指数 & $J=-\sum_{i=1}^{n}\left(P_{i} \ln P_{i}\right) / \ln S=H^{\prime} / \ln S$ \\
Sorenson 相似距离系数 & $C_{S}=2 j(a+b)$ \\
\hline
\end{tabular}

$* n$ 表示每个样品中检测到的条带数, $S$ 表示 DGGE 检测到的不同条带的总和 $\left(S \geqslant n_{\text {max }}\right.$ ), $P_{i}$ 表示样品中各 个条带的灰度占样品总灰度的百分含量. $j$ 表示两个样品共有的条带数, $a, b$ 分别表示两个样品各含有的 DGGE 条带数.

采用单因素方差分析 (One-way ANOVA) 检验浮游细菌丰度, DGGE 条带数, Shannon-Wiener 指数, Simpson 指数和 Pielou 指数是否存在显著的季节变化; 配对 $t$ 检验 (Paired $t$-test) 用于比较浮游细菌丰度, DGGE 条带数, Shannon-Wiener 指数, Simpson 指数和 Pielou 指数在梅梁湾和湖心是否存在显著差异. 
采用非公制多维尺度分析 (Nonmetric Multidimensional Scaling, NMDS) 比较浮游细菌种群基因组成的相 似性, 分析浮游细菌种群内部不同基因型的动态变化 ${ }^{[4,19]}$. 根据 marker 的位置, 可以对不同凝胶上的样品 进行综合分析. 将电泳图谱转化为由 $0 、 1$ 组成的二元矩阵,计算样品间的 Sorenson 相似系数系数 $\left(C_{S}\right)$ (表 1 ), 得到相似矩阵进行 NMDS 分析. NMDS 结果通常用二维图表示, 样品在二维图中的距离可以反映样品 间的相似程度, 就本研究而言, 样品距离越近, 表示浮游细菌种群的组成越相似.

\section{2 实验结果}

\section{1 浮游细菌数量}

在梅梁湾和湖心,浮游细菌丰度随时间的变化趋势如图 $2 \mathrm{a} 、 \mathrm{~b}$ 所示. One-way ANOVA 显示两个采样点 的浮游细菌丰度均呈现出显著的时间变化规律. 在梅梁湾,夏季和秋季浮游细菌的丰度明显高于冬季和春 季 (图 2a), 在湖心, 浮游细菌丰度随时间的变动范围小于梅梁湾 (表 2), 但同样观察到夏季和秋季的细菌 数量高于冬季和春季 (图 $2 \mathrm{~b}$ ). 在梅梁湾, 浮游细菌数量的年均值为 $7.86 \times 10^{6} \mathrm{cells} / \mathrm{ml}$, 比湖心的年均值 5 . $88 \times 10^{6} \mathrm{cells} / \mathrm{ml}$ 高 $34 \%$ (表 2 ). 配对 $t$ 检验显示浮游细菌数量在两个采样点间存在显著差异,梅梁湾的浮 游细菌丰度显著高于湖心 (表 2 )。

梅梁湾
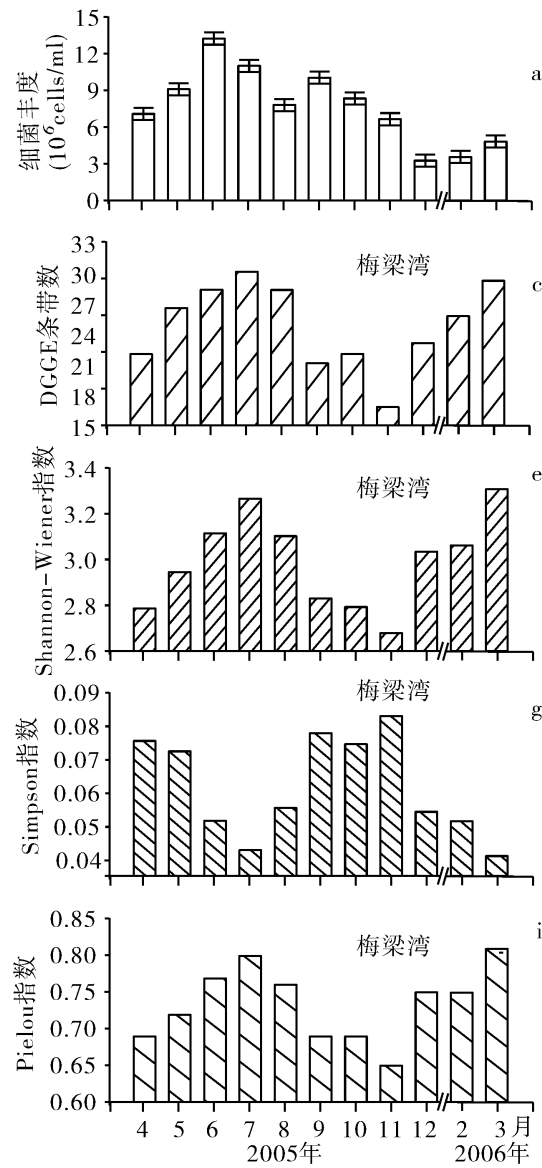

采样时间
湖心
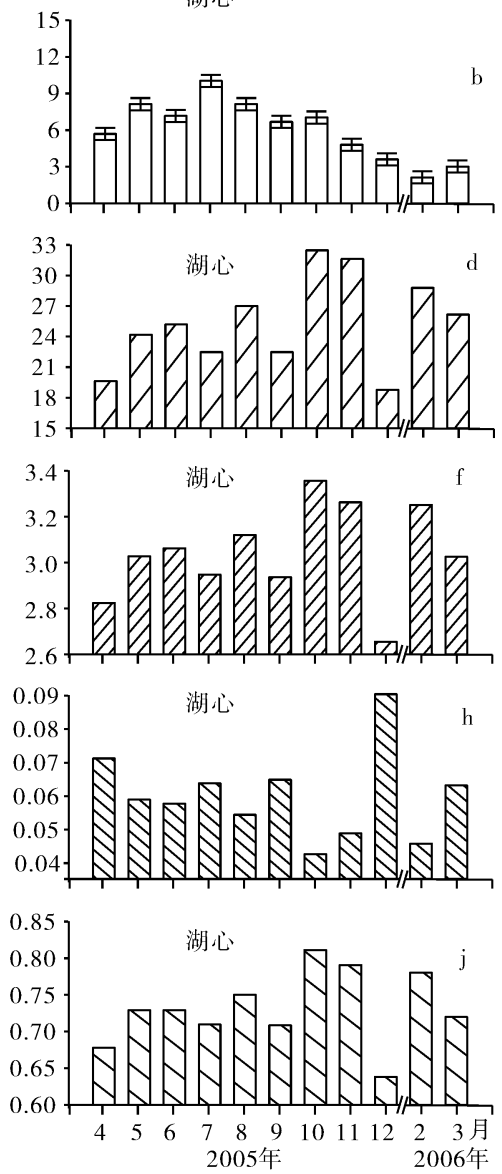

采样时间

图 2 浮游细菌种群细胞丰度 $(\mathrm{a}$ 和 $\mathrm{b}) 、$ DGGE 条带数 $(\mathrm{c}$ 和 $\mathrm{d}) 、$ Shannon-Wiener 指数 $(e$ 和 $f) 、$

Simpson 指数 $(\mathrm{g}$ 和 $\mathrm{h})$ 、Pielou 指数 $(\mathrm{i}$ 和 $\mathrm{j}$ ) 随时间的变化

Fig. 2 Seasonal variation of bacterioplankton abundance ( $a$ and b), DGGE band number ( $c$ and $d$ ),

Shannon-Wiener index $(e$ and $f)$, Simpson index $(g$ and $h)$, Pielou index ( $i$ and $j)$. 
表 2 浮游细菌种群特征参数的年平均值和变化范围及显著性检验

Tab. 2 Annual mean and range of community characteristic indices and results of significant test

\begin{tabular}{cccc}
\hline & 梅梁湾平均值 $($ 范围 $)$ & 湖心平均值 $($ 范围 $)$ & $t$ 检验显著性 \\
\hline 细菌数量 $\left(10^{6}\right.$ cells $\left./ \mathrm{ml}\right)$ & $7.86(3.41-13.40)^{*}$ & $5.88(2.11-9.81)^{*}$ & 0.004 \\
DGGE 条带数 & $26.3(17-32)^{*}$ & $25.2(19-34)^{*}$ & 0.536 \\
Shannon-Wiener 指数 & $3.00(2.67-3.31)^{*}$ & $3.00(2.69-3.34)^{*}$ & 0.949 \\
Simpson 指数 & $0.061(0.041-0.083)^{*}$ & $0.061(0.042-0.089)^{*}$ & 0.907 \\
Pielou 指数 & $0.74(0.65-0.81)^{*}$ & $0.72(0.64-0.81)^{*}$ & 0.554 \\
\hline
\end{tabular}

* One-way ANOVA 分析显示随时间变化具有显著差异, $p<0.05$.

\section{2 PCR-DGGE 分析浮游细菌种群的基因组成}

采用针对细菌 $16 \mathrm{~S}$ rDNA 的特异性引物对提取的浮游细菌总 DNA 进行 PCR 扩增, 所有样品均获得了 特异扩增片段, 目的片段长度约 $600 \mathrm{bp}$ (含 GC 夹), 包含细菌 $16 \mathrm{~S} \mathrm{rDNA}$ 的 V3 至 V6 高变区 (图 3). 纯化后 的 PCR 产物通过变性梯度凝胶电泳的分离, 每个样品均得到若干条带, 但各个样品的条带在数量和位置上 均有差异 (图 4). 通过对 DGGE 电泳图谱的分析,梅梁湾和湖心检测到的迁移位置不同的条带分别为 55 条 和 51 条. 在梅梁湾 (图 2c), 7 月份电泳分离得到的条带数最多为 32 条, 11 月份的条带数最少仅 17 条, 两 个月份间相差 15 条, DGGE 条带数年平均值为 26.3. 在湖心 (图 2d), 10 月份检测到的 DGGE 条带数最多 为 34 条, 12 月份的条带数最少为 19 条, 两个月份也相差 15 条, 年平均值为 25.2 , 低于梅梁湾. One-way ANOVA 显示两个采样点的 DGGE 条带数均呈现出显著的时间变化规律. 对同一月份两个采样点的配对 $t$ 检验结果显示, DGGE 条带数在两个采样点间不存在显著差异 (表 2).

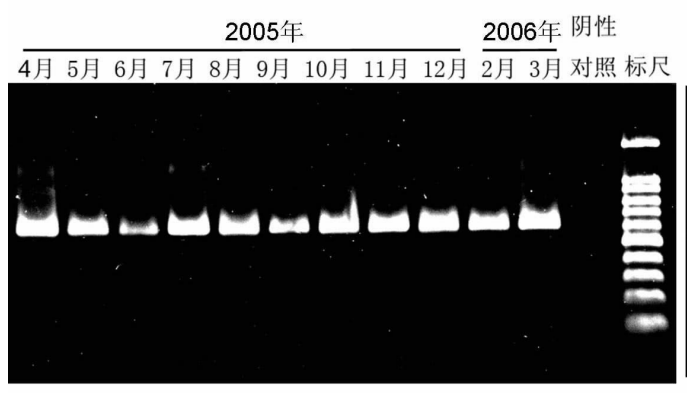

a
2005年

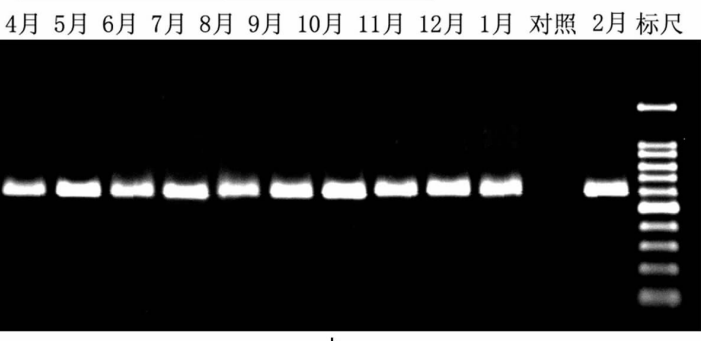

b

图 3 PCR 扩增细菌 16S rDNA 片段,其中 (a) 梅梁湾; ( b ) 湖心 ; NC 表示阴性对照

Fig. 3 PCR amplified bacterial partial 16S rDNA sequence (a) Sampling site in Meiliang Bay;

(b) Sampling site at lake center; NC denotes to negative control

\section{3 浮游细菌种群基因多样性的季节变化}

在选取的两个采样点,各种群特征指数随时间均呈现出一定的季节变化特征. 由图 4 可见,同一采样 点的 DGGE 条带数、Shannon-Wiener 指数、Simpson 指数和 Pielou 指数的变化具有显著的相关性. 随着 DGGE 条带的增加, Shannon-Wiener 指数和 Pielou 指数增大, 而 Simpson 指数相应降低, 表明随浮游细菌种 类的增加, 种群多样性和均匀度增大, 相应的优势度减小. 在湖心, Shannon-Wiener 指数的最小值出现在 11 月份 (图 2f), 在梅梁湾该指数的最小值出现在 12 月份 (图 2e), 两采样点出现种群多样性最低值的时间较 为接近. 在梅梁湾, Shannon-Wiener 指数的最高值出现在 7 月份 (图 2e), 而在湖心则出现在 10 月份 (图 2f), 两个采样点的差异较大. 通过对 Shannon-Wiener 指数、Simpson 指数和 Pielou 指数的 One-way ANOVA 显示, 两个采样点的各指数均随时间变化显著. 梅梁湾与湖心 Shannon-Wiener 指数的年平均值都为 3.00, Simpson 指数的年均值也相等为 0.061 , 只是梅梁湾的 Pielou 指数的年均值略高于湖心, 配对 $t$ 检验显示浮 游细菌种群的多样性,优势度和均匀度在两个采样点间不存在显著的差异 (表 2). 


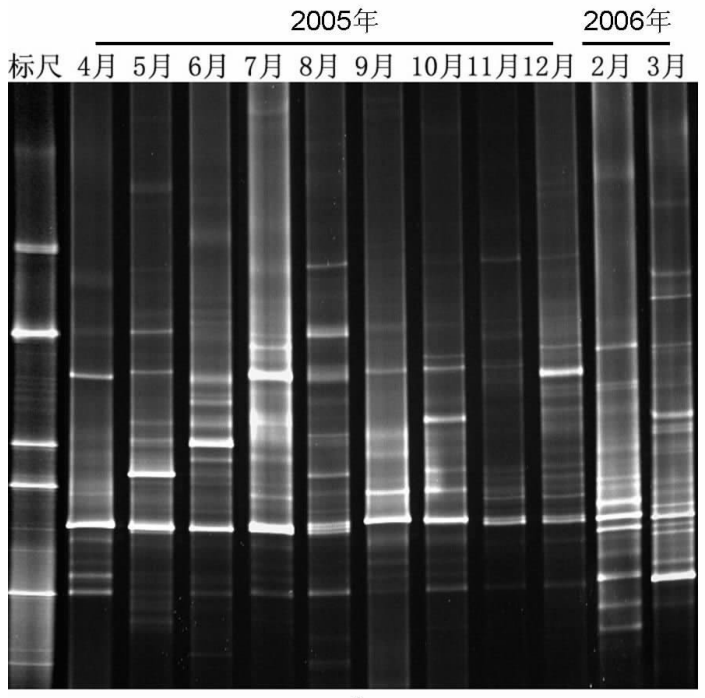

a
2005年

2006年
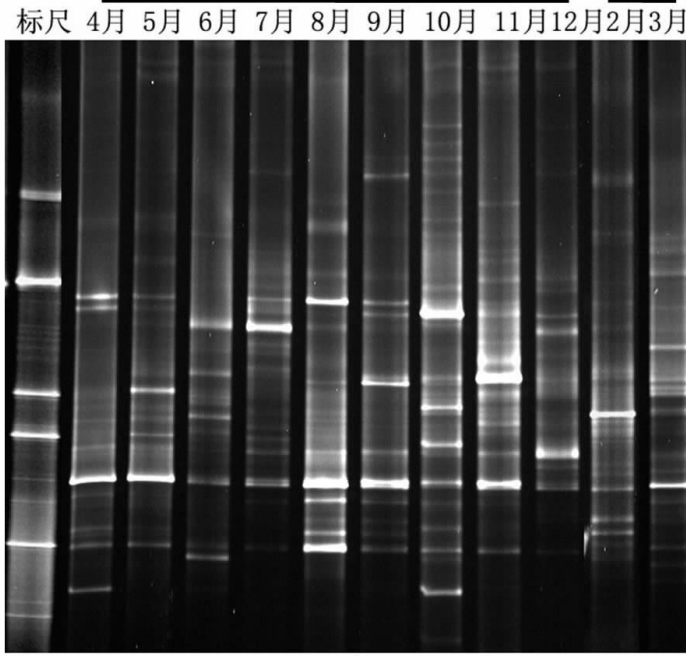

b

图 4 浮游细菌种群组成的 DGGE 分析, 其中 (a) 梅梁湾采样点; (b) 湖心采样点

Fig. 4 Bacterioplankton community composition analyzed by DGGE

(a) Sampling site in Meiliang Bay; (b) Sampling site at lake center

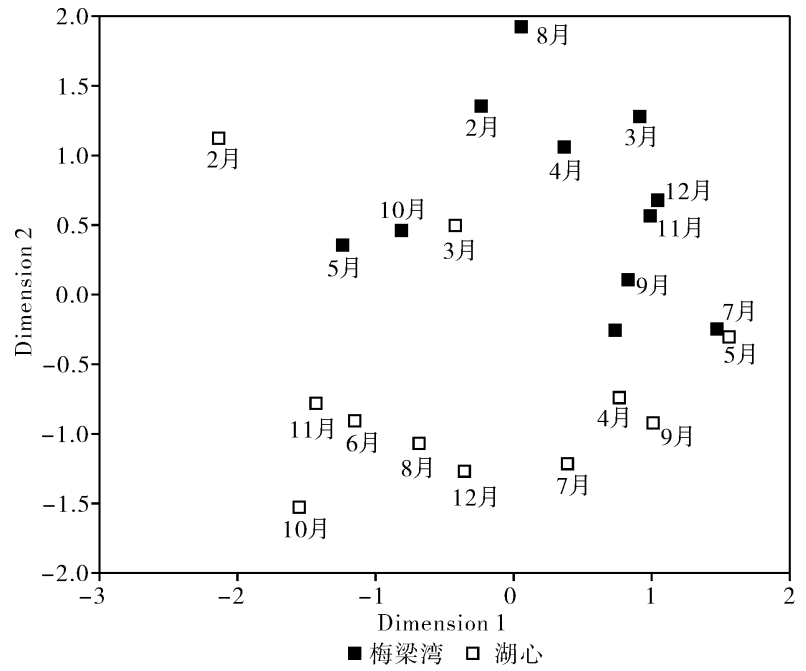

图 5 NMDS 比较浮游细菌种群组成的相似性及季节变化 ( Stress $=0.0010)$, 梅梁湾; $\square$ 湖心

Fig. 5 Nonmetric multidimensional scaling (NMDS) diagram showing the changes in the bacterioplankton community structure in Meiliang Bay and lake center $(\square)$ during the seasonal cycles ( Stress $=0.0010$ )

根据浮游细菌种群 DGGE 电泳图谱生成的相似矩阵,经过非公制多维尺度 (NMDS) 分析, 各样品在二 维空间中的相对位置如图 5 所示. 样品间的距离反映其种群基因组成的相似程度,由图 5 可见,在湖心采 样点, 11 与 12 月份样品位置十分接近, 表明组成两个种群的细菌基因类型较为相近. 在排序图中不存在位 置完全重合的样品, 即不存在种群组成完全相同的样品, 因此浮游细菌种群的基因组成存在不同程度的时 空变化. 同一采样点的各样品在图中的位置相对较为集中,例如梅梁湾的样品集中在图的上部,而湖心的 
样品大多集中在图的下部,不同采样点的样品在图中基本可以区分开来,表明浮游细菌种群组成的空间差 异较为显著. 对同一采样点各样品的分析显示, 相邻采样时间的样品, 其种群组成的变化没有固定的方向, 呈现较大的随机性.

\section{3 讨论}

PCR-DGGE 在适合的条件下可以分辨只有一个碱基不同的 DNA 序列; 可以同时分析多个样品, 直观地 反映不同样品基因多样性的差异, 适合于分析微生物种群组成的动态变化. 尽管这一技术也可能会在 DNA 提取和 PCR 扩增过程中丢失某些含量相对较少的物种的序列信息 ${ }^{[20,21]}$, 但是与传统的微生物分离培养方 法相比较,PCR-DGGE 的结果可以更为准确和全面地反映环境中微生物群落优势种的差异, 尤其是可以证 实那些无法在室内培养, 但又具有一定生态学功能的种类的存在. 目前, 采用 PCR-DGGE 分析环境微生物 样品结果的准确性已经得到了其他方法的印证 ${ }^{[22]}$.

\section{1 浮游细菌种群基因多样性的季节变化}

单因素方差分析表明不论是在梅梁湾还是湖心,浮游细菌丰度、DGGE 条带数、Shannon-Wiener 指数、 Simpson 指数和 Pielou 指数均表现出显著的季节变化,即夏、秋季节浮游细菌的丰度、基因多样性和种群的 均匀度较高, 而冬、春季节则较低. 高光 ${ }^{[9]}$ 和吴庆龙等 ${ }^{[23]}$ 对太湖浮游细菌数量的研究也显示出类似的季节 变化特征. Muylaert 等 ${ }^{[3]}$ 研究了不同营养程度的浅水湖泊中微食物网各营养级的相互作用, 发现在富营养 湖泊中浮游细菌主要受到浮游藻类的调控 (bottom-up regulation), 而受浮游动物的影响很小. 浮游藻类分泌 到胞外以及细胞破裂产生的有机物是细菌分解作用的物质基础,而且在某些时空条件下可能成为细菌营养 物质的主要来源 ${ }^{[24,25]}$. 根据陈宇炜等 ${ }^{[26]}$ 对太湖浮游藻类的长期监测及本文作者对浮游藻类生物量的同步 分析显示,太湖浮游藻类的生物量通常在夏季达到一年中的最大值,较高的生物量可以并一直保持到秋季, 而在冬季和春季处于一年中的低水平. 这同本研究观察到的浮游细菌丰度和多样性的季节变化具有时间 上的一致性, 由此可以推断在太湖, 浮游细菌的季节变化与浮游藻类的季节变化也存在一定的相关性. 其 他研究者进行的实验室及野外的研究也证实了这种相关性的存在 ${ }^{[27,28]}$.

\section{2 浮游细菌基因多样性的空间差异}

配对 $t$ 检验显示浮游细菌丰度存在空间上的显著差异 (表 2 ), 梅梁湾的浮游细菌丰度明显高于太湖湖 心. 高光 ${ }^{[9]}$ 和吴庆龙等 ${ }^{[23]}$ 对比梅梁湾和湖心浮游细菌的丰度也发现相同的空间差异. 尽管配对 $t$ 检验显 示 DGGE 条带数, Shannon-Wiener 指数, Simpson 指数和 Pielou 指数在两个采样点间不存在显著差异, 但根 据以种群组成相似性为基础的 NMDS 分析显示, 浮游细菌种群组成存在较为明显的空间差异 (图 5 ). 由于 DGGE 条带数和种群多样性指数的变化仅能反映浮游细菌种群内不同基因型的数量, 以及各种基因型相对 含量的变化情况, 不能体现种群组成的差异, 因此本研究进一步采用 NMDS 分析各样品浮游细菌种群结构 的相似性是必要的. 根据上述结果可以推断,在梅梁湾和湖心, 虽然浮游细菌不同基因型的数量及多样性 特征指数的差异并不显著,但浮游细菌种群内主要建群种的基因型存在显著差异.

浮游细菌的种群组成受到多种生物及非生物因子的调控,环境因子与浮游细菌种群组成的相关分析表 明环境因子空间分布的不均匀性是造成浮游细菌种群组成存在差异的重要原因 ${ }^{[29,30]}$. 吴庆龙等 ${ }^{[23]}$ 的研究 显示在梅梁湾和大太湖, 对微食物网结构具有显著影响的环境因子存在差异, 在梅梁湾与营养盐有关的环 境因子为主要的驱动因子, 而在大太湖与风浪扰动作用密切相关的总悬浮物 (TSS) 成为主导因子. 由此可 以推断主导环境因子的差异是导致浮游细菌种群组成存在空间差异的原因之一. 通过进一步研究环境因 子与浮游细菌种群的相互作用, 将有助于揭示不同湖区浮游细菌种群动态变化的调控规律.

\section{3 浮游细菌种群特征与基因型变化的关系}

环境因子的作用往往导致浮游细菌种群丰度、细胞大小、细胞含碳量等发生变化,这些种群外部特征的 改变可能是由两种类型的内部变化引起 ${ }^{[31]}$ : 一种是细菌细胞的表型特征发生了变化,而种群的基因组成未 发生明显变化. 通常情况下, 细菌的细胞具有较强的可塑性,在一定范围内可以根据环境条件的变化,例如 根据可利用有机物性质的变化,调节细胞的代谢活性, 表面附着特征, 调控关键酶的表达及细胞生长速率 等. 而另一种原因是细菌种群内部发生了不同基因型的演替,即不同环境条件下的细菌种群由不同基因型 
的细菌构成,这种基因型组成的根本变化也可以使种群呈现截然不同的外部特征. 本研究通过对浮游细菌 种群的 DGGE 电泳图谱和 NMDS 分析显示, 两采样点的浮游细菌种群均随时间出现了基因组成的变化, 由 此可以推断在太湖,浮游细菌种群基因组成的变化是导致浮游细菌细胞大小、含碳量以及胞外酶活性等在 随环境因子的变化产生变化的重要内因. 在了解了太湖浮游细菌种群基因多样性变化规律的基础上, 对其 种群具体构成及其主要功能群的更深人的认识还有待对 DGGE 检测中所获得的每个条带进行测序, 并与 GenBank 中的已知序列比对获得.

\section{4 结论}

PCR-DGGE 可以用于研究太湖浮游细菌种群的基因多样性及其时空变化. 通过对 DGGE 电泳图谱的 分析显示太湖浮游细菌种群具有丰富的多样性. 细菌丰度、DGGE 条带数、Shannon-Wiener 指数、Simpson 指 数和 Pielou 指数均呈现显著的季节变化: 夏季和秋季浮游细菌的丰度、基因多样性及种群的均匀度较高, 而 冬季和春季浮游细菌的丰度、基因多样性及种群的均匀度较低. 浮游藻类的季节变化可能是导致浮游细菌 种群季节变化的主要原因. 配对 $t$ 检验及 NMDS 分析显示, 梅梁湾与湖心浮游细菌的丰度及主要建群种的 基因型存在显著的空间差异. 对浮游细菌种群基因组成及时空变化的研究有助于进一步分析浮游细菌同 浮游藻类及浮游动物之间的相互作用,认识太湖微食物网的结构和功能及其调控机制.

致谢: 感谢中国科学院南京地理与湖泊研究所的吴庆龙博士对实验的指导, 感谢曹焕生博士、张民、吴晓东 对采样过程的协助. 感谢杨州博士对稿件撰写及修改提供的宝贵意见.

\section{5 参考文献}

[1] Kisand V, Nõges T. Abiotic and biotic factors regulating dynamics of bacterioplankton in a large shallow lake. FEMS Microbiol Ecol, 2004, 50: $51-62$

[2] Brock T D. The study of microorganisms in situ: progress and problems. Symp Soc Gen Microbiol, 1987, 41: $1-17$.

[3] Muylaert K, van der Gucht K, Vloemans N et al. Relationship between bacterial community composition and bottom-up versus top-down variables in four eutrophic shallow lakes. Appl Environ Microbiol, 2000, 66 : $4740-4750$.

[4] Van der Gucht K, Vandekerckhove T, Vloemans N et al. Characterization of bacterial communities in four freshwater lakes differing in nutrient load and food web structure. FEMS Microbiol Ecol, 2005, 53: 205 -220 .

[5] Lindström E S. Bacterioplankton community composition in a boreal forest lake. FEMS Microbiol Ecol, $1998,27: 163-174$.

[6] Yannarell A C, Triplett E W. Geographic and environmental sources of variation in lake bacterial community composition. Appl Environ Microbiol, 2005, 71(1): $32-38$.

[7] Lindström E S. Bacterioplankton community composition in five lakes different in trophic status and humic content. Microb Ecol, 2000, 40 : $104-113$.

[8] Kent A D, Jones S E, Yannarell A C et al. Annual patterns in bacterioplankton community variability in a humic lake. Microb Ecol, 2004, 48: 550 - 560

[9] 秦伯强, 胡维平, 陈伟民等编著. 太湖水环境演化过程与机理. 北京: 科学出版社, 2004:248 - 313.

[10] Velji M I, Albright L J. Improved sample preparation for enumeration of aggregated aquatic substrate bacteria. In: Kemp P, Sherr B, Sherr E et al. eds. Handbook of Methods in Aquatic Microbial Ecology. Lewis, $1993: 139-142$.

[11] Porter K G, Feig Y S. The use of DAPI for identifying and counting aquatic microflora. Limnol Oceanogr, 1980, 25: $943-948$.

[12] Kjärstin H, Boström K S, Åke Hagström et al. Optimization of DNA extraction for quantitative marine bacte- 
rioplankton community analysis. Limno Oceanogr: Methods, 2004, 2: $365-373$.

[13] Riemann L, Wingding A. Community dynamics of free-living and particle-associated bacterial assemblages during a freshwater phytoplankton bloom. Microb Ecol, 2001, 42: $274-285$.

[14] Muyzer G, De Waal E C, Uitterlinden A G. Profiling of complex microbial populations by denaturing gradient gel electrophoresis analysis of polymerase chain reaction amplified genes coding for 16S rRNA. Appl Environ Microbiol, 1993, 59: 695 - 700.

[15] Kousuke I, Manabu F. Optimization of annealing temperature to reduce bias caused by a primer mismatch in multitemplate PCR. Appl Environ Microbiol, 2004, 67(8) : 3753 - 3755.

[16] Shannon C E, Weaver W. The mathematical theory of communication. Urbana IL: University of Illinois Press, $1949: 117$.

[17] Simpson E H. Measurement of diversity. Nature, 1949, 163: 688.

[18] Pielou E C. Ecological Diversity. New York: John Wiley \& Sons, 1975.

[19] van Hannen E J, Zwart G, van Agterveld M P et al. Changes in Bacterial and Eukaryotic Community Structure after Mass Lysis of Filamentous Cyanobacteria Associated with Viruses. Appl Environm Microbiol, $1999, \mathbf{6 5}(2): 795-801$.

[20] Luna G M, Anno A D, Danovaro R. DNA extraction procedure: a critical issue for bacterial diversity assessment in marine sediments. Environ Microbiol, 2006, 8: 308 - 320.

[21] Polz M F, Cavanaugh C M. Bias in template-to-product ratios in multitemplate PCR. Appl Environ Microbiol, 1998, 64: $3724-3730$.

[22] Diez B, Pedrós-Alió C, Marsh T L et al. Application of Denaturing Gradient Gel Electrophoresis (DGGE) to study the diversity of marine picoeukaryotic assemblages and comparison of DGGE with other molecular techniques. Appl Environ Microbiol, 2001,67 (7) : 2942 - 2951.

[23] Wu Q L, Chen Y W, Xu K D et al. Intra-habitat heterogeneity of microbial food web structure under the regime of eutrophication and sediment resuspension in the large subtrophical shallow lake Taihu, China. Hydrobiologia, $2007, \mathbf{5 8 1}: 241$ - 254 .

[24] Baines S B, Pace M L. The production of dissolved organic matter by phytoplankton and its importance to bacteria-patterns across marine and fresh-water systems. Limnol Oceanogr, 1991, 36: 1078 - 1090.

[25] Jensen L M. Phytoplankton release of extracellular organic carbon, molecular weight composition, and bacterial assimilation. Mar Ecol Prog Ser, 1983, 11: 39 - 48.

[26] Chen Y W, Qin B Q, Katrin T et al. Long-term dynamics of phytoplankton assemblages: Microcystis-domination in Lake Taihu, a large shallow lake in China. J Plankton Res, 2003, 25(1):445 - 453.

[27] Rooney-Varga J N, Girwat M W, Savin M C et al. Links between phytoplankton and bacterial community dynamics in a coastal marine environment. Microb Ecol, 2005, 49: 163 - 175.

[28] van Hannen E J, Mooij W, van Agterveld M P et al. Detritus-dependent development of the microbial community in an experimental system: qualitative analysis by denaturing gradient gel electrophoresis. Appl Environ Microbiol, 1999, 65: $2478-2484$.

[29] Jasti S, Sieracki M E, Poulton N J et al. Phylogenetic diversity and specificity of bacteria closely associated with Alexandriun spp. and other phytoplankton. Appl Environ Microbiol, 2005 , 71(7) : 3483 - 3494.

[30] Pearce D A. The structure and stability of the bacterioplankton community in Antarctic freshwater lakes, subject to extremely rapid environmental change. FEMS Microbiol Ecol, 2005, 53: $61-72$

[31] Riemann L, Steward G F, Azam F. Dynamics of bacterial community composition and activity during a mesocosm diatom bloom. Appl Environ Microbiol, 2000, 66(2) : 578 - 587. 